\title{
Understanding and Interpretation of Revelation 1:8 by some Asante-Twi Speaking Scholars
}

\begin{abstract}
Without Bible translation, it would have been very difficult for the Church to perform its preaching and teaching mandate in a new environment, for Scriptures were written in Hebrew, Aramaic, and Koine Greek. A faithful translation of the Bible allows the Church to help the local indigenes to understand the text and theologise aright in their mother-tongue. However, the Asante-Twi Bible, an example of a translated Bible has some text that have not been translated accurately. One of such is the translation of Revelation 1:8, the study area for this paper. The present translation of the Greek text in the Asante-Twi Bible does not allow God to possess an Ashanti name. This article delves into the study of the text with the lens of Ashanti scholars in the Asante-Twi context and an exegesis of the Greek text to look for the sameness in the Asante-Twi. The paper argues for the translation of Revelation 1:8 as: Mene Ahycase ne Awiee

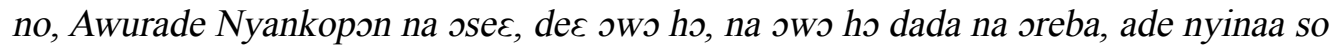
Tumfor no ("I am the Alpha and Omega," says the Lord God, who is, who was, and who is to come, the Almighty).
\end{abstract}

Keywords: Bible Translation, Mother-tongue, The Alpha and Omega, Asante people, Asante name, Asante-Twi Bible, to alpha kai to omega.

\section{INTRODUCTION}

There is no perfect translation whatsoever in the world. However, a faithful translation of Scripture into the mothertongue of a people is necessary to achieving relevant theological understanding, as the lack of a good translation impedes effective understanding of the text. ${ }^{2}$ There are situations in Bible translations where some texts are not translated to meet the theological understanding, religio-cultural setting and worldview of the target audience, but 'carried wholly' into the newly translated language to make them look as if they form part of the language. There are times text in the original languages-Hebrew, Aramaic and Koine Greek - are translated to make them pronounceable in the mother-tongue of the target audience without bearing in mind the religio-cultural, language portrayal and worldview of the indigenes. ${ }^{3}$ Translation in this manner makes it difficult for the word of God to have a home $\mathrm{e}^{4}$ in the target audience. Therefore, the need for Bible translations which involve re-interpretation of scriptures to enable the salvific message to offer theological understanding to the target audience is laudable.

The methodology employed in this work was the mother-tongue biblical hermeneutics. A mixed method was employed in this study for data collection. Primary data from three (3) Asante-Twi scholars were collected by way of interviews for theological understanding of the text. Interviewees were scholars and ministers of the gospel who preach and teach the gospel message in Asante-Twi language. In addition, was a Bible translator who ensures local indigenes access the gospel message in their mother-tongue. Secondary sources of information that were beneficial for the work were gleaned from relevant materials from the study area.

\footnotetext{
Joseph M. Y. Edusa-Eyison, "The Bible in Dialogue with African life and thought and the role of the Mother tongue: The Contribution of Kwesi Dickson to a new Creative stage in Theology," Journal of African Christian Thought, Vol. 10, (2007): 8-17.

3 Kwasi Adomako and Bright Amo, "Some Translation Practices in the Asante Twi Bible," SKASE Journal of Translation and Interpretation, Vol. 7 (1), 2014: 9-27.

4 Making the gospel message to have an indigenous identity.
} 


\section{BIBLE TRANSLATION}

According to Bratcher, translation involves bringing to life a foreign thing in a new environment; making it to have the flesh and blood of the new environment, and not just giving it a new dress. ${ }^{5}$ Hence, translating the Bible (or Scriptures) into Asante-Twi language is like a good modern Asante-Twi translation being read to make it looks like as though it was produced in Asante-Twi language by an Asante, written at the time the original text was written, and giving a reflection of the total context of the original work in language and terms understandable in our time. ${ }^{6}$ According to Thomas AttaAkosah, scripture translation is done to offer the ability of understanding Scriptures better, and not the other way round. ${ }^{7}$ Jean-Claude Loba-Mkole also postulates that Bible translation must be carried out in such a manner where the religiocultural setting and worldview of the target audience is taken into consideration to help the indigenes get a clearer understanding of the text without difficulty. ${ }^{8}$ But these at times are not considered by some interpreters and translators due to the insecurity about their own language and the yearning to keep the mystery of the text in the source language; accepting that other languages are more important than their mother-tongue. ${ }^{9}$

\section{Asante Names and their Significance}

Names have special qualities due to the role they play in people's life; they make one unique from others. Aside connecting individuals to their social and cultural histories, names also help to develop knowledge of how the systems came into being. ${ }^{10}$ Among Ghanaians, names of objects, deities, and for God, as well as personal names are given and or received from the relationship of religious, mythical, social and historical realities. ${ }^{11}$ Some few Asante (Ashanti) names explain the fact. Begyina (come and stay), an Asante name for a child fated to cyclical birth and death. The name Nyamekye (God's gift or a gift from God) is given to a person whose fatherhood is not acknowledged or who is given birth by parents advanced in years. Also, Asante Kotoko (Asante Porcupine) is used for the celebration of Asante's military tactics. ${ }^{12}$ The Asantes do not downplay the importance of names. They value their significance, for meanings are easily known to them. The wrong pronunciation or misuse of a person's name usually calls for correction, followed by an apology by the offending person, especially when they are members of the society or community. ${ }^{13}$

\section{MOTHER-TONGUE BIBLICAL HERMENEUTICS}

Mother-tongue Biblical Hermeneutics or studies is "a discipline devoted to the interpretation and reinterpretation of biblical texts in languages considered by speakers as their first languages into which they were born." ${ }^{4}$ According to Kuwornu-Adjaottor, this method involves engaging in a scholarly manner with Bibles translated in the language of the indigenes in order to grasp its saying and meaning to the users. ${ }^{15}$ It employs the mother-tongue Bibles - the translations of the Bible into such languages into which people are born and nurtured. ${ }^{16}$ Quarshie explains mother-tongue as a person's language in which they were born into, and fully develop with. ${ }^{17}$ He distinguishes mother-tongue from vernacular. According to him, while mother-tongue is people's foremost language, in cases where they are able to speak other languages they might have learnt later, vernacular is their common language for their region. ${ }^{18}$ However, Ekem thinks that mother-tongue and vernacular can be the same, especially when it is used widely across the geographical

Robert G. Bratcher, "The Art of Translating," Bible Translator (9) (1958): 84-9.

6 Emmanuel F. Asamoah, An Assessment of the translation of TO A $\Lambda$ A KAI TO $\Omega$ as Alfa ne Omega no in the Greek New Testament (Revelation 1:8) and Asante-Twi Twere Kronkron (Sacred Writings), Unpublished MPhil Thesis, (Kumasi: KNUST, 2019 ), 34.

7 Thomas Atta-Akosah, "The Language factor in African Christian Mission: Bible Translation and Biblical Interpretation in the Church in African Church," Journal of African Christian thought, Vol. 15(2), (2012): 20-5.

8 Jean-Claude Loba-Mkole, "History and theory of Scripture translations," Hervormde Teologiese Studies (HTS), vol. 64(1), (2008): 254-266.

9 Eugene Nida and Charles R. Taber, The Theory and Practice of Translation, (Leiden: E. J. Brill, 1969), 101.

10 Benjamin Blount, Personal Names (2015), Accessed on April 25, 2020, from https://www.researchgate.net/publication/303519288_ Personal Names

11 Willie E. Abraham, The Mind of Africa (Chicago: Chicago University Press, 1962), quoted in Abu Shardow Abarry, "The Significance of Names in Ghanaian Drama," Journal of Black Studies, Vol. 22, No. 2 (December 1991), 157.

12 Abu S. Abarry, "The Significance of Names in Ghanaian Drama,” Journal of Black Studies, Vol. 22 (2), (December, 1991): 157-167. It uses solace in how the porcupine defends itself from attackers.

13 Blount, Personal Names (2015), Accessed on April 25, 2020, from https://www.researchgate.net/publication/303519288_Personal_Names

14 John David K. Ekem, Early Scriptures of the Gold Coast (Ghana): The Historical, Linguistic and Theological Settings of the Ga, Twi, Mfantse and Ewe Bibles (Manchester: St. Jerome Publishing, 2011), 10.

15 Jonathan E. T. Kuwornu-Adjaottor, "Bible Studies and Biblical Studies: An Interface," The Bible, Cultural Identity, and Missions, (2016), 386-406.

16 Jonathan E. T. Kuwornu-Adjaottor, "Mother-Tongue Biblical Hermeneutics: A Current Trend in Biblical Studies in Ghana," JETERAPS, 3(4): 575-579.

17 Benhardt Y. Quarshie, "Doing Biblical Studies in the African Context-The Challenge of Mother-Tongue Scriptures," Journal of African Christian Thought 5, (2002): 4-14.

$18 \quad$ Ibid, 4-14. 
extremities. ${ }^{19}$ Bibles translated in the mother-tongue offer Africans (or Ghanaians) the chance to explain the meaning of Scripture from their own worldview. This methodology undertakes an exegesis of the text under study to find out how it was accurately translated into the language of the natives (receptors) for them to receive the meaning as intended by the original author(s).

\section{ASANTE-TWI BIBLE TRANSLATION OF REVELATION 1:8}

Undoubtedly, the largest ethnic group in Ghana is the Akan, and the greater part of the southern sector of Ghana is occupied by them. The Asantes (or Ashanti) form part of the Akan ethnic group. The Asantes are native to the Ashanti Region. ${ }^{20}$ The language of the Asantes is Asante-Twi, which is the mostly spoken language in Ghana. ${ }^{21}$ The Asantes form part of the Akan which historically migrated from the Sahel region and the Savannas of West Africa. ${ }^{22}$ In Ghana, the Akan language is a constellation of vernaculars which include Asante-Twi, Akuapem-Twi, Mfantse, Wassa, Kwahu, Bono, Agona, Akyem, and Akwamu. ${ }^{23}$ The Bible has been translated into the Asante-Twi language. However, some of the text reveal a lack of theological understanding and language portrayal. One of such is Revelation 1:8.

\section{Problematic Translation of Revelation 1:8 in Asante-Twi Bible}

The translation of Revelation 1:8 from the original language into the Asante-Twi language rendered the name or title the

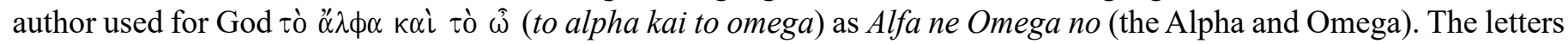
in the text were transliterated to make it pronounceable in the Asante-Twi language, without translating and interpreting the text to bring out the significance of names to the Asante-Twi speaking people. ${ }^{24}$ This gives a kind of picture to the Asante-Twi speaking people that God speaks no other language than the original languages the biblical authors wrote. This makes it difficult for Asante-Twi Bible readers to understand fully who God is from the text, and why the author revealed God's existence in that manner. Additionally, it becomes difficult for Asante-Twi speaking people to get the theology behind the title or name used by the author to reveal God to his hearers, for in the Asante-Twi language, there is no word like Alfa ne Omega. ${ }^{25}$ Furthermore, it becomes difficult for those who have not received some level of theological education to understand the theology behind the text, for it is only when one learns the Biblical languages they are able to access the Word of God. ${ }^{26}$ And lastly, it also makes it difficult for the word of God to "enter" into the heart of Asante-Twi readers; since "If you talk to a man in a language he understands, that goes to his head. If you talk to him in his language, that goes to his heart." ${ }^{27}$ But God wants his own (and humankind in general) to know him in their culture and language; he expresses all the earthly languages ${ }^{28}$ (cf. Romans 6:11, The Message Bible).

\section{EXEGESIS OF REVELATION 1:8}

\section{A brief background to the Book of Revelation}

The book of Revelation also known as the Apocalypse of John was written by John at Patmos Island, between 92-96 AD. ${ }^{29}$ This was when he was exiled for reaching fellow Christians with the gospel message. ${ }^{30}$ Aside encouraging the churches not to engage in the evil activities of the time, John also admonished them to put their hope in the Lord who will in no time come to their rescue. ${ }^{31}$ John received the message of the book from God via an angel in symbols which

19 John D. K. Ekem, Priesthood in Context: A Study of Priesthood in Some Christian and Primal Communities of Ghana and its Relevance for Mother-Tongue Biblical Interpretation (Accra, GH: SonLife Press, 2009), 188.

20 World Atlas, Who Are the Akan People? Accessed on April 25, 2020, from https:/www.worldatlas.com/articles/who-are-the-akan-people. html.

21 John D. K. Ekem, Early Scriptures of the Gold Coast (Ghana), 50.

22 World Atlas, Who Are the Akan People? Accessed on April 25, 2020, from https://www.worldatlas.com/articles/who-are-the-akan-people. html.

23 John David K. Ekem, Early Scriptures of the Gold Coast (Ghana), 50

24 Emmanuel Foster Asamoah, "A Comparative Study of to Alfa Kai to Omega in the Greek New Testament (Revelation 1:8) and Asante-Twi Bible," MOTBIT Vol. 2(1). 2020: 70-7.

25 Ibid, 70-7.

26 David Dewey, A User's Guide to Bible-Translations: Making the Most of Different Versions, (Illinois: InterVasity Press, 2004$), 29$.

27 "Mandela in his own words," CNN homepage, June 26, 2008, accessed November 23, 2017 at 21:53 GMT, http://edition.cnn.com/2008/ WORLD/africa/06/24/mandela.quotes/

28 Asamoah, "A Comparative Study of to Alfa Kai to Omega in the Greek New Testament (Revelation 1:8) and Asante-Twi Bible,": $70-7$.

29 There are others who hold an earlier date, thus "before AD 70" which was during the reign of Nero. But both the internal and external evidences coupled with eye witnesses suggest the later date. For further information, read; Michael Rydelnik and Michael Vanlaningham (eds.), The Moody Bible Commentary (Chicago: Moody Publishers, 2014), 1999.

30 Ibid, 1999.

31 Asamoah, An Assessment of the translation of TO А ФА KAI ТО $\Omega$ as Alfa ne Omega no in the Greek New Testament (Revelation 1:8) and Asante-Twi Twere Kronkron (Sacred Writings), 56-7. 
was one of the means for communication at the time..$^{32}$ For the atmosphere of the Roman province at the time was permeated with the symbols of the old fertility cults and of the deified state and emperor, which were broadcasted by the temples and public buildings, by the law courts, by the theatres and gladiatorial games, and above all, by the coinage. ${ }^{33}$ This may not have meant very much for the provincial, but it was blasphemy for some Christians who were raised upon the Jewish scriptures. ${ }^{34}$ Christians had to decide what to do in this environment of idolatry and immorality ${ }^{35}$ - the two serious enemies the early church had to contend with. Failing to participate sent the signal of resistance to the state and emperor - who demanded to be worshipped as a deity. ${ }^{36}$

Christians in the province of Asia, the location of the seven churches, were put under pressure to succumb to the worship of the emperor. While some Christians held on to their faith, others recanted theirs for fear of death. Christians who denounced their faith were praised to offer prayer with incense and wine to the emperor's statute, and beyond that to rain insults and curses on God (Christ).${ }^{37}$ As a staunch Christian and a missionary of God, John failed to succumb to the pressures of the time and even went ahead to encourage other Christians to hold on to their faith. ${ }^{38}$ John had to be exiled to the island of Patmos for his missionary activities (Rev. 1:9). It was from this backdrop that the author wrote the Apocalypse to inspire and encourage his fellow brothers and sisters in the Lord who felt like turning their back on God for the world, not to abandon their faith. ${ }^{39}$

\section{Revelation 1:8}

\section{Greek Rendition}

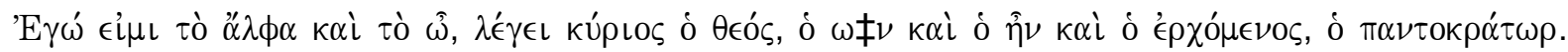

\section{Transliteration}

Egō eimi to alfa kai to ō, legei kurios ho Theos, ho ōn kai ho èn kai ho erchomenos, ho Pantokratō.

\section{Structure of the Text}

The whole text gives the revelation of God as the ruler of the world. As an unchangeable One, God is also not limited in power. ${ }^{40}$ The text reveals the attributes of God that he shares with no one; making him the One who is above all and has the ability to interfere in the affairs of human history. ${ }^{41}$ The text has two main parts; the first bringing out clearly as

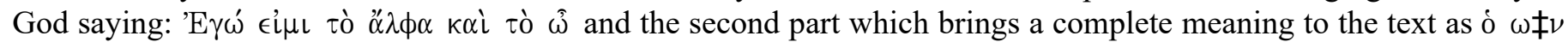

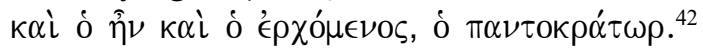

\section{God's Revelation of His Lordship}

Ego is a personal pronoun in Greek meaning "I". ${ }^{43}$ As a word in the nominative case, Ego has a forceful emphasis when joined to a verb as in Luke 3:16, or shows a direct opposite of someone or something else as in Matthew $3: 14 .{ }^{44}$ It must be noted that this is not a rigid rule in the Greek language, for there are times Ego is used to suggest otherwise as in Matthew 10:16 and John 10:17. ${ }^{45}$ However, taking a look at the circumstances of the audience, the earlier one fits in the context. The speaker would want to put emphasis on who he is, as well as to present himself as someone who is directly opposite the deities of the land. By parsing, Ego is a first person singular personal pronoun in the nominative case. This recognises the speaker as the subject of the sentence. As such, it places forceful emphasis on the verb eimi, which as a substantive verb has the strength of a predicate meaning, "to be," which is "to exist" as in Revelation 1:4; "to stay, remain, be in a place" as in Mark 1:45 and Luke 1:80; "to live" as in Matthew 2:18; and "to be found" as in Luke 16:1,

\footnotetext{
32 Alan Bandy, "The Hermeneutics of Symbolism: How to Interpret the Symbols of John's Apocalypse," Southern Baptist Journal of Theology 14.1 (2010): 46-58.

33 Ibid, 46-58. J. P. M. Sweet, Revelation (Philadelphia: The Westminster Press, 1979), 28.

34 Sweet, Revelation 31.

35 Fornication, on the other hand, was an accepted practice in the province. Prostitution which included males and females was a consistent part of the fertility cults. See; Sweet, Revelation, 33.

36 Brian K. Blount, Revelation: A Commentary (Louisville, Kentucky: Westminster John Knox Press, 2009), 9; J. P. M. Sweet, Revelation, 33; Merrill C. Tenney, New Testament Survey, Revised (Grand Rapids, Michigan: Wm. B. Eerdmans Publishing Company, 1985$), 384$.

37 T. D. Barnes, "Legislation against the Christians," Journal of Roman Studies 58, 1968, quoted in J. P. M. Sweet, Revelation (Philadelphia: The Westminster Press, 1979), 29.

38 Michael Rydelnik and Michael Vanlaningham (eds.), The Moody Bible Commentary (Chicago: Moody Publishers, 2014$), 1999$.

39 Ibid, 1999-2000.

40 Asamoah, "A Comparative Study of to Alfa Kai to Omega in the Greek New Testament (Revelation 1:8) and Asante-Twi Bible,": 70-7.

41 Emmanuel Foster Asamoah, "A Comparative Study of to Alfa Kai to Omega in the Greek New Testament (Revelation 1:8) and Asante-Twi Bible,": 70-7.

42 Ibid, 70-7.

43 Joseph H. Thayer, Thayer's Greek-English Lexicon of the New Testament (Grand Rapids, Michigan: Baker Book House, 1999$), 167$.

44 Ibid, 167.

45 Ibid, 167.
} 
19 and John 3:1.46 This shows that the subject of the text (in this case, God) exists, lives, or remains in the place, and does not cease to exist. ${ }^{47}$ As a copula, eimi joins the subject with the predicate, to reveal the character, nature, power, dignity, and greatness of the person or thing in the text. ${ }^{48}$ By parsing, eimi is a first person present active singular verb that indicates that the speaker is referring to himself to be in existence. ${ }^{49}$ Thus, John tells his hearers how God reveals his nature, power and greatness in a forceful manner to the world..$^{50}$ The narrator wants all readers to know that God exists and continues to exist. ${ }^{51}$

The Greek letter ${ }^{\prime} \lambda \phi \alpha(a l p h a)$ and $\hat{\omega}$ (omega) are the first and last alphabet of the Greek language respectively. According to Thayer, ${ }^{\prime} \alpha \phi \alpha$ (alpha) opens the series of the Greek alphabet, and $\hat{\omega}$ (omega) is the closing and last letter of the Greek alphabet. ${ }^{52}$ The author used the first and last letters of the Greek alphabet as symbols for God; the beginning and the end. ${ }^{53}$ Thus, as $\alpha^{\prime} \lambda \phi \alpha$ (alpha) opens the series of the Greek alphabet and $\hat{\omega}$ (omega) closes, so the author wants to reveal that both the beginning of everything proceeds from the speaker (God), and ends with him. John qualified both

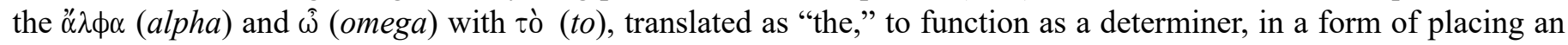
emphasis on the symbols chosen for God. ${ }^{54}$ Thus, as a definite article, to (to) sets apart the symbols— $\hat{\omega}$ (omega) - from other symbols that had permeated the Roman province as at the time. Hence, God's name revealed as the Alpha and Omega. ${ }^{55}$ Again, the determiner makes it clearer that God is both the Creator and the Redeemer, and the Final Judge of all things. ${ }^{56} \mathrm{He}$ alone has the power to begin or start something and bring it to an end, and is identified as the Lord of everything that occurs through time. ${ }^{57} \mathrm{He}$ is the Lord over everything from creation (the beginning of the world) to the consummation (the end) of history.

The Greek word legei comes from the root word legw which is "to say or speak". As a third person present singular verb, legei is translated as "he/she/it is saying or speaking". This brings out clearly that only one person is speaking, and he is God. In context, "he is saying" best fits. ${ }^{58}$

The verb legei qualifies the noun nominative masculine singular kurios ho Theos translated literally as "the Lord God"; to make it clearer that the Lord God is the one speaking in the text. on is the participle of eimi ("to be") verb translated as "exist". ${ }^{59}$ Since participles are verbal adjectives, on could be translated as "existing". As a nominative masculine singular, on is translated as "I am existing." This brings it clearer that God continues to exist. ${ }^{60}$

\section{God's Revelation of His Immutability and Eternity}

èn is the third person imperfect indicative active singular verb which could be translated as "I was." As imperfect indicative tense, en qualifies the subject Eimi to become "I was existing" or "I existed". Who was existing? The context of the passage tells that it is God, for the pronoun is personal singular and the verb, in the third person singular.

ho erchomenos comes from the root word erchomai which is translated as "to come or go". ${ }^{61}$ This means God is to come or go. The verb is in the present nominative masculine which renders it as "coming or going". In context, "coming" best fits. Again, in the middle voice, the verb indicates a situation where the "subject acts in relation to himself." ${ }^{2} 2$ That is to say, God is referring to Himself that He will be "coming". This means that the subject is God and no one else is making the statement.

These verbs are joined with the conjunction kai translated as "and," "even," or "also". In context, "and" is chosen to bring out the meaning of the sentence.

The word Pantokratō comes from two Greek words Pas and krateo. Pas is translated as "all, any, every, or the whole" ${ }^{63}$ Krateo is translated as "dominion, might, power, or strength" ${ }^{64}$ It also means "to get possession of," and "to 
hold in the hand, to hold fast, or to continue to hold, to retain". ${ }^{65}$ God as Pantokrato means that God is powerful and has in His hands any and every kind. As if that is all, He continues to hold and retain what He possesses. In effect, God is the "ruler of all" or "Almighty". ${ }^{66}$ In parsing, ho Pantokrato is the nominative and masculine singular noun. This is very significant, for it reveals God as the subject of the text. The ho places much emphasis on God as the "Almighty"; hence translated as "the Almighty".

\section{UNDERSTANDING AND INTERPRETATION OF REVELATION 1:8 BY SOME ASANTE-TWI SCHOLARS}

On the question of whether Alfa ne Omega no (the Alpha and Omega) should be the translation for the Alpha and Omega, the researcher had different interpretations from some Asante-Twi scholars. Alex K. Anum ${ }^{67}$ is of the view that

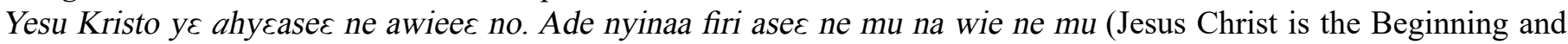
the End. All things proceeded from Him and ends in Him). Anum's interpretation cited above that Jesus Christ is the Beginning and the End is not far from the truth that God is the one who from the beginning has been existing and will continue to exist at the end of all time. He is the One who controls the start and close of time and is rightly recognised as the Lord of everything that occurs through time.$^{68} \mathrm{He}$ is the Lord over everything from creation (the beginning of the world) to the consummation (the end) of history. This interpretation brings out the divinity of Jesus Christ completely as being equal with God the Father (cf. John 10:30; Isa. 41:10). It also affirms John's description of Jesus Christ: "All things were made by him; and without him was not anything made that was made" (John 1:3, KJV).

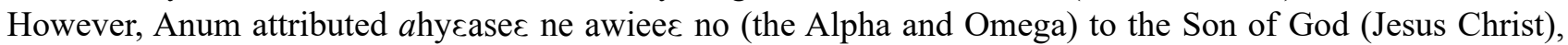
instead of God. He might have been influenced by a reference text in the Book of Revelation where the author disclosed Jesus as saying, "I am the Alpha and Omega". ${ }^{69} \mathrm{He}$ is not far from the truth since Jesus Christ is also God [the Son], and is equal with God. ${ }^{70}$ Notwithstanding, Anum dealt with the text under study and interpreted Alpha and Omega as ahycase $\varepsilon$ ne awiee $\varepsilon$ no (the beginning and the end).

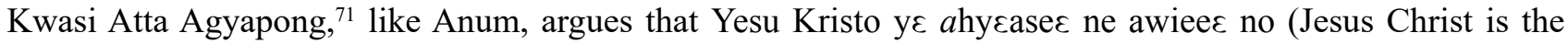
Beginning and the End). But unlike Anum who ended, Agyapong goes on to say: Ono (Yesu Kristo) ne A ne $Y^{72}$ no wo Asante-Twi atwerede $\mathrm{mu}$ (He [Jesus Christ] is the A and Y in the Asante-Twi alphabet). Agyapong's interpretation of Jesus Christ as the 'Beginning and the End' as well as the 'A and $\mathrm{Y}$ ' in the Asante-Twi alphabet cited above brings out two titles of Jesus Christ, all meaning same. ${ }^{73}$ Agyapong's interpretation suggests that the 'Beginning and the End' and the 'A and the $\mathrm{Y}$ ' in Asante-Twi mean same in the context of Revelation 1:8. According to Agyapong, Jesus Christ is not Alfa ne Omega no to the Asante-Twi speaking people, since Alfa ne Omega no which is a transliteration of the Alpha and the Omega are Greek letters. He is of the view that since Asante-Twi speaking people also have alphabet, beginning with $A$ and ending with $Y$, it is better referring to Jesus Christ as such as it makes meaning to them than Alfa ne Omega no. This affirms Loba-Mkole's belief that the religio-cultural setting and worldview of the target audience, which includes the portrayal of their language, should be considered in translation. ${ }^{74}$

Like Anum, Agyapong also translated the Alpha and the Omega as ahycase ne awiee no and attributed it to Jesus Christ instead of God. However, he is not far from the truth since Jesus Christ is also God the Son and is equal with God. ${ }^{75}$ Notwithstanding, Agyapong dealt with the text under study and interpreted Alpha and Omega as ahycase $\varepsilon$ ne awiee $\varepsilon$ no (the beginning and the end) and A ne Y no (the A and the Y).

Wonderful Adjei Arthur ${ }^{76}$ revealed that in Bible translation, borrowing a word from the Source Language (SL), finding a word's equivalence in the Receptor Language (RL) or transliterating a word from the SL to the RL is often given premium when it comes to words that have strange terminology in a RL. In explaining further, he used 'jasper' (Rev. 21:11, 18, 19) to prove his point. According to him, since 'jasper' is not common to the Asante people, it would

${ }_{65}$ Thayer, Thayer's Greek-English Lexicon of the New Testament, 359.

66 Bible Works Greek LXX/BNT for Windows, Revelation 1:8 (Bible Works, LCC, 2003).

67 Interview with Alex K. Anum on July 2, 2019. He is a Reverend Minister and holds a Master of Arts in Pentecostal Studies from Pentecost University College, Sowutuom and a Certificate in Akan language from Enchi Training College. He is the District Minister of Kwashieman Official Town (Accra) of The Church of Pentecost Ghana.

68 Blount, Revelation: A Commentary, 39.

69 Revelation 22:13 reads "I am the Alpha and the Omega, the First and the Last, the Beginning and the End" (NLT).

70 Henry B. Swete, The Apocalyse of St. John (Grand Rapids, Michigan, USA: WM B. Eerdmans Publishing Company, 1968), clx.

71 Interview with Kwasi Atta Agyapong on July 2, 2019. He holds a Master of Arts in Pentecostal Studies from Pentecost University College, Sowutuom. He is the District Minister of Nkawkaw Asuboni District of The Church of Pentecost, Eastern Region, Ghana.

72 This is the Asante-Twi alphabets; (Upper Case) “A, B, D, E, E, F, G, H, I, K, L, M, N, O, J, P, R, S, T, U, W, and Y”. (Lower Case) “a, b, d, $\mathrm{e}, \varepsilon, \mathrm{f}, \mathrm{g}, \mathrm{h}, \mathrm{i}, \mathrm{k}, \mathrm{l}, \mathrm{m}, \mathrm{n}, \mathrm{o}, \mathrm{o}, \mathrm{p}, \mathrm{r}, \mathrm{s}, \mathrm{t}, \mathrm{u}, \mathrm{w}$, and y”. Source: Omniglot: The Online Encyclopaedia of Writing Systems \& Languages, Accessed from https://www.omniglot.com/writing/akan.htm on October 28, 2019.

73 Excerpts from Interview with Kwasi Atta Agyapong.

74 Loba-Mkole, "History and theory of Scripture translations," 254.

75 Swete, The Apocalyse of St. John, clx.

76 Wonderful Adjei Arthur is a translator with the Bible Society of Ghana, Kumasi. The researcher had a telephone interview with him on June 30,2019@13:41 GMT. 
be transliterated as 'gyaspa'. Hence, the interpretation of the Alpha and Omega as Alfa ne Omega no. Adjei Arthur's explanation for translating words that are considered as strange terminology from the SL to the RL seems not to be so for recent translation works. These translations seek to move from rendering, as closely as possible the semantic and syntactic structures of the second language, to the exact contextual meaning of the original to enable the target audience to understand text in their religio-cultural context which meets the morphological and word appropriateness. ${ }^{77}$ Nida believes that Bible translators and interpreters tow Adjei Arthur's method of translation and interpretation as a result of the insecurity about their own language and the yearning to keep the mystery of the text in the SL; accepting that other languages are more important than their mother-tongue. ${ }^{78}$ As a way to show that the Asante-Twi language is not inferior to other languages such as the biblical languages, Bible translators and interpreters have, in the recent AsanteTwi Bible (2012), translated 'jasper' as ahwehweboo ${ }^{79}$ which makes meaning to the Asante-Twi readers. This helps Asante-Twi users of the Bible to understand the term as used by John in the Asante-Twi environment, thereby enabling them to theologise aright. This translation shows that borrowing a word from the SL, finding a word's equivalence or transliterating from SL to RL is not a fixed rule in Bible translation, especially in recent translations.$^{80}$ This affirms Nida's assertion that any message can be communicated to any audience in any language provided that the most effective form of expression is found. ${ }^{81}$

\section{Summary of the interpretations}

With the exception of Adjei Arthur whose principle for translating strange terminology does not allow local indigenes to theologise aright, all the Asante scholars interviewed seem to speak a common language for the translation of Revelation

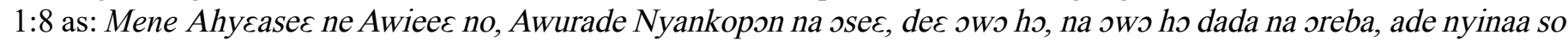
Tumfor no ("I am the Alpha and Omega," says the Lord God, who is, who was, and who is to come, the Almighty). God existed before creation, and the world will come to an end in Him. He has no beginning and no end, for himself is the beginning and the end. He is the Lord over everything from creation (the beginning of the world) to the consummation (the end) of history. This affirms Chad Brand et al., position of the sovereignty and eternal nature of God as being the "First and the Last, the Beginning and the End" ${ }^{82}$ And it generates the same effect aimed at by the original recipients. ${ }^{83}$

\section{CONCLUSION}

The translation of Revelation 1:8 in the Asante-Twi Bible shows a lack of Asante-Twi language portrayal and theological understanding of the revelation of God to users of the Asante-Twi Bible users. The 'non-Asante-Twi' nature for God's disclosure is a clear example of not giving God a home in the Asante culture, let alone, speak the Asante-Twi. It also limits the ordinary Asante-Twi readers from giving God a name in their culture which is through the interplay from the relationship of religious, mythical, social and historical realities ${ }^{84}$ The interpretations of the text by Asante-Twi scholars show the shortfall of the current translation which does not meet the religio-cultural thought and context of Revelation 1:8. A study of the text suggest that a translation and interpretation that fits the theological knowledge, religio-cultural

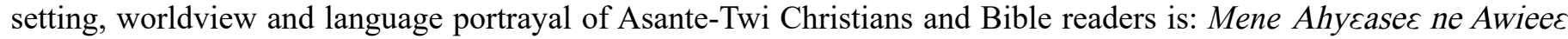
no, Awurade Nyankopon na ose $\varepsilon$, de $\varepsilon$ owo ho, na owo ho dada na oreba, ade nyinaa so Tumfoo no ("I am the Alpha and Omega," says the Lord God, who is, who was, and who is to come, the Almighty).

\section{BIBLIOGRAPHY}

Abarry, Abu Shardow. "The Significance of Names in Ghanaian Drama," Journal of Black Studies, Vol. 22, No. 2 (Dec. 1991), 157-167.

Abraham, Willie E. The Mind of Africa. Chicago: Chicago University Press, 1962.

Adomako, Kwasi and Bright Amo, "Some Translation Practices in the Asante Twi Bible," SKASE Journal of

77 Peter Newmark, Approaches to Translation (Oxford: Pergamon Press, 1981), 39.

78 Nida and Taber, The Theory and Practice of Translation, 101.

79 Ahwehweboo is literary translated as "mirror-like stone". This is more meaningful as compared to "gyaspa" which is a "non-Asante-Twi" word, and does not also give meaning to the Ashanti in the Asante-Twi language as intended by the original author.

${ }^{80}$ A text does not have a fixed meaning. It can be translated or remoulded in the religio-cultural thought of a reading community. See: Jacques Derrida, "Structure, Sign and Play in the Discourse of Human Sciences." In Writing and Difference, trans. Alan Bass (Chicago: University of Chicago Press. 1978): 278-93; Norman L. Geisler, Baker Encyclopaedia of Christian Apologetics (Grand Rapids, MI: Baker Academic, 2007), 192-3.

81 Eugene A. Nida, "The paradoxes of translation," The Bible Translator 42, (2a) (1991): 5-25.

82 Chad Brand, Charles Draper and Achie England (eds.), Holman Illustrated Bible Dictionary, (Nashville, Tennessee: Homan Bible Publishers, 2003), 50.

83 Eco Umberto, Experiences in Translation (Toronto: University of Toronto Press, 2001), 14.

84 Willie E. Abraham, The Mind of Africa (Chicago: Chicago University Press, 1962), quoted in Abu S. Abarry, "The Significance of Names in Ghanaian Drama," Journal of Black Studies, 22 (2), (December 1991): 157-167. 
Translation and Interpretation, vol. 7 (1), 2014: 9-27.

Asamoah, Emmanuel Foster, "A Comparative Study of to Alfa Kai to Omega in the Greek New Testament

(Revelation 1:8) and Asante-Twi Bible," MOTBIT Vol. 2(1), 2020: 70-7.

, An Assessment of the translation of TO A $\Lambda \Phi$ A KAI TO $\Omega$ as Alfa ne Omega no in the Greek New Testament (Revelation 1:8) and Asante-Twi Twere Kronkron (Sacred Writings), Unpublished MPhil Thesis. Kumasi:

Kwame Nkrumah University of Science and Technology, 2019.

Atta-Akosah, Thomas, "The Language factor in African Christian Mission: Bible Translation and Biblical Interpretation in the Church in African Church," Journal of African Christian thought, Vol. 15(2), (2012): 2025.

Aune, David E. Revelation 3 vols. Nashville: Thomas Nelson, 1997/1998.

Bandy, Alan, "The Hermeneutics of Symbolism: How to Interpret the Symbols of John's Apocalypse," SBJT 14.1 (2010): 46-58.

Barnes, T. D. "Legislation against the Christians," Journal of Roman Studies 58, 1968.

Bible Works Greek LXX/BNT for Windows, Revelation 1:8. Bible Works, LCC, 2003.

Biblesoft PC Study Bible, CD-ROM, version 5.0.

Blount, Benjamin, Personal Names. 2015. Accessed online from https://www.researchgate.net/publication/303519288_Personal_Names on April 25, 2020.

Blount, Brian K. Revelation: A Commentary. Louisville, Kentucky: Westminster John Knox Press, 2009.

Brand, Chad, Charles Draper and Archie England (eds.), Holman Illustrated Bible Dictionary. Nashville, Tennessee: Homan Bible Publishers, 2003.

Bratcher, Robert G. "The Art of Translating," Bible Translator (9) (1958): 84-9.

Derrida, Jacques "Structure, Sign and Play in the Discourse of Human Sciences." In Writing and Difference, trans. Alan Bass. Chicago: University of Chicago Press. 1978: 278-93.

Dewey, David, A User's Guide to Bible-Translations: Making the Most of Different Versions. Illinois: InterVasity Press, 2004.

Edusa-Eyison, Joseph M. Y. "The Bible in Dialogue with African life and thought and the role of the Mother tongue: The Contribution of Kwesi Dickson to a new Creative stage in Theology," Journal of African Christian Thought, Vol. 10, (2007): 8-17.

Ekem, John D. K. Early Scriptures of the Gold Coast (Ghana): The Historical, Linguistic and Theological Settings of the Ga, Twi, Mfantse and Ewe Bibles. Manchester: ST. Jerome Publishing, 2011.

Priesthood in Context: A Study of Priesthood in Some Christian and Primal Communities of Ghana and its Relevance for Mother-Tongue Biblical Interpretation. Accra, GH: SonLife Press, 2009.

Geisler, Norman L. Baker Encyclopedia of Christian Apologetics. Grand Rapids, MI: Baker Academic, 2007.

Kuwornu-Adjaottor, J. E. T. "Bible Studies and Biblical Studies: An Interface", in The Bible, Cultural Identity, and Missions, ed. Daniel Berchie, Daniel Kwame Bediako and Dziedzorm Reuben Asafo. Cambridge Scholars Publishing, 2016. "Mother-Tongue Biblical Hermeneutics: A Current Trend in Biblical Studies in Ghana," JETERAPS, 3(4): 575-579.

Loba-Mkole, Jean-Claude, "History and theory of Scripture translations," Hervormde Teologiese Studies (HTS), vol. 64(1), (2008): 254-266.

Lockyer, Herbert F. F. Bruce and R. K. Harrison (eds.). Illustrated Dictionary of the Bible. Nashville, Tennessee: Thomas Nelson Publishers, 1986.

Mandela, Nelson, "Mandela in his own words." CNN homepage, June 26, 2008, accessed online from http://edition. cnn.com/2008/WORLD/africa/06/24/mandela.quotes/ at November 23, 2017 at 21:53 GMT.

Moberly, R. B. "When Was Revelation Conceived?," Bib 73.3 (1992): 376-393.

Mounce, William D. The Analytical Lexicon to the Greek New Testament. Grand Rapids: Zondervan Publishing House, 1993.

Newmark, Peter, Approaches to Translation. Oxford: Pergamon Press, 1981.

Nida, Eugene A. "The paradoxes of translation," The Bible Translator 42, (2a) (1991): 5-25.

Nida, Eugene and Charles R. Taber, The Theory and Practice of Translation. Leiden: E. J. Brill, 1969.

Omniglot: The Online Encyclopaedia of Writing Systems \& Languages, Accessed from https://www.omniglot. com/writing/akan.htm on October 28, 2019.

Quarshie, Benhardt Y. "Doing Biblical Studies in the African Context-The Challenge of Mother-Tongue Scriptures," Journal of African Christian Thought, 5 (2002): 4-14.

Rydelnik, Michael and Michael Vanlaningham (eds.), The Moody Bible Commentary. Chicago: Moody Publishers, 2014. 
Sproul, R. C. The Last Days According to Jesus. Grand Rapids: Baker, 2000.

Strong's Greek Dictionary, Power BibleCD 4.3 Software.

Sweet, J. P. M., Revelation. Philadelphia: The Westminster Press, 1979.

Swete, Henry B. The Apocalyse of St. John. Grand Rapids, Michigan, USA: WM B. Eerdmans Publishing Company, 1968.

Tenney, Merrill C. New Testament Survey Revised. Grand Rapids, Michigan: Wm. B. Eerdmans Publishing Company, 1985.

Thayer, Joseph H. Thayer's Greek-English Lexicon of the New Testament. Grand Rapids, Michigan: Baker Book House, 1999.

Umberto, Eco, Experiences in Translation. Toronto: University of Toronto Press, 2001.

WorldAtlas, Who Are the Akan People? Accessed Online from https://www.worldatlas.com/articles/who-are-the-akan-people.html on April 25, 2020. 